\title{
Evaluation of a Teaching Assistant Program in Online Education
}

\author{
Shelley N. Armstrong, $\mathrm{PhD}$ \\ Walden University, Minneapolis, Minnesota, United States \\ (iD https://orcid.org/0000-0003-1887-8818 \\ Kirsten Lupinski, EdD \\ Walden University, Minneapolis, Minnesota, United States \\ (iD https://orcid.org/0000-0002-0615-2748
}

Michelle M. Burcin, $\mathrm{PhD}$

Walden University, Minneapolis, Minnesota, United States

Kimberly Kato, EdD

Walden University, Minneapolis, Minnesota, United States

(iD) https://orcid.org/0000-0002-9906-7541

Marsha Kaufman, $\mathrm{PhD}$

Walden University, Minneapolis, Minnesota, United States

(iD https://orcid.org/o00o-0001-9758-3414

Contact: shelley.armstrong@mail.waldenu.edu

\begin{abstract}
Online student success is determined by several factors, including learning effectiveness, access (academic, technical, and administrative support), faculty satisfaction, and student satisfaction. These factors are part of the Online Learning Consortium's Pillars of Quality Online Education, which were established to ensure all students are provided a quality education, with high levels of student engagement, instructor feedback and interaction, and experiential learning opportunities. Using Teaching Assistants (TAs) in the virtual classroom is not a traditional practice for most online institutions, but is a strategy that can have a positive impact on these factors. This exploratory research study discusses a TA program that was developed, implemented, and evaluated over 3 years. Fifteen $(n=15)$ doctoral students were hired to provide teaching support to high-risk courses in the undergraduate programs. Background, recruitment, onboarding, division of course responsibilities, data, and outcomes of the 3-year TA programs are discussed in alignment with the five pillars. Findings suggest the addition of TAs in online education is a potentially useful strategy to improve student learning outcomes, scale, access, and faculty and student satisfaction.
\end{abstract}

Keywords: distance learning; online education; teaching assistants; quality framework

Date Submitted: August 6, 2020 | Date Published: April 2, 2021

\section{Recommended Citation}

Armstrong, S., Lupinski, K., Burcin, M., Kato, K., \& Kaufman, M. (2021). Evaluation of a teaching assistant program in online education. Journal of Educational Research and Practice, 11, 46-63.

https://doi.org/10.5590/JERAP.2021.11.1.04 


\section{Introduction}

Online education is often associated with low completion and graduation rates and a lack of experiential learning opportunities (Haynie, 2015). Critics also challenge that online programs are inferior to brick-andmortar programs in terms of quality, offerings, and employment preparation (Supiano, 2017). While enrollment in online programs continues to rise, scrutiny and quality control target many for-profit online universities (Beaver, 2017). To address this scrutiny, the Online Learning Consortium (OLC) established the Five Pillars of Quality Online Education, a framework that helps online institutions identify goals and measure progress toward these goals for successful online learning. These five pillars are:

- learning effectiveness

- scale

- access

- faculty satisfaction

- $\quad$ student satisfaction (OLC, 2020)

Learning effectiveness means that online student's learning should be equivalent to the learning of traditional students. Instructors and curriculum designers should take advantage of their online environment to provide learning experiences that are specific to their student population. Scale is advantageous to online institutions to ensure students receive a quality education at an affordable value. Access provides students with university and program information along with links to available resources such as support for technical issues, financial aid, disabilities services, and other university systems. Faculty satisfaction means that instructors find the online teaching and learning experience personally rewarding and have the support of the institution. Student satisfaction is impacted by a variety of factors: interaction with professors and peers, individualized interaction and engagement, timely feedback on assignments and inquiries, and available support services (OLC, 2020).

Based on the OLC's vision and mission to establish a high standard in online learning, all online universities have an ethical and legal responsibility to emulate brick-and-mortar offerings and to give students what they pay for, which is quality education and solid job preparation. Over the past several years, researchers at one fully online university noted a few areas of concern: (a) lower completion rates in undergraduate first-year courses and (b) high faculty burnout in undergraduate first-year courses. After reviewing previous literature on how to increase learning effectiveness, student access, student satisfaction, and faculty satisfaction, the university created and implemented a teaching assistant (TA) program, as TAs in online courses may provide students with comparable opportunities as face-to-face programs.

Therefore, the purpose of this study was to explore the implementation of a 3-year TA program based on the OLC's pillars at one large, for-profit, fully online, accredited university. One undergraduate program at the university hired $15(n=15)$ doctoral students for 3 years to provide support in high-risk and first-year courses. During each term, the TAs were assigned to faculty mentors to support instructional delivery, evaluation, student access, and outreach. Background, recruitment, onboarding, data collection, as well as best practices were reviewed in the evaluation of the program. 


\section{Literature Review}

\section{Learning Effectiveness}

Overall learning effectiveness, including attaining outcome standards and retention of students, has been shown to improve with the use of TAs. Gatlin and Alexander (2010) found faculty agreed or strongly agreed that the use of a TA in their class "substantially increased student engagement" (86\%), "improved student learning/performance" (93\%), and provided "quicker and more consistent feedback" (100\%) (p. 11). The inclusion of TAs in courses was shown to enhance the learning outcomes and, in turn, improve students' grades and experiences. The additional classroom attention offered by the Tas, through feedback and interaction, endorsed higher retention rates when compared to courses without TAs. Crowe et al. (2014) and Huffmyer and Lemus (2019) reported similar conclusions that the addition of TAs resulted in students achieving higher performance levels than in classes without TAs.

\section{Scale: Cost-Effectiveness and Commitment}

According to Carless and Boud (2018), feedback is one of the most powerful influences on learning, yet, one of the most time-consuming. Implementing a smaller enrollment cap warrants faculty to be fully committed to students, ensuring timely and individualized feedback, grading, and attention. However, this design is not realistic for many online courses due to the increased feedback demand by students in large enrollment courses and the increased expense to universities. The addition of TAs in the classroom is a method that can enhance cost-effectiveness while allowing universities to increase both course enrollment and offerings.

The inclusion of a TA allows a decreased student-to-instructor ratio without compromising a student's learning experience and satisfaction (Hoessler \& Stockley, 2016). The added level of resources and student support by TAs allows for larger class sizes while maintaining the quality feedback and interaction, which, over time, contributes to higher university revenue. As TAs are hired at a fraction of the pay as professors (Weidert et al., 2012), courses with a professor and TA together can have a progressive increase in enrollment without lessening the experience of high-quality student engagement, feedback, and interaction with only a minimal financial impact on the university (Herrman \& Waterhouse, 2010).

\section{Access}

TAs have been shown to increase support access, services, and available assistance within specific courses. Conner and Rubenstein (2014) stated students perceived TAs as more accessible due to age and a willingness to succeed. TAs share a student status resembling the students enrolled in courses. Therefore, students feel more comfortable asking the TAs questions because they feel they can relate to them. The presence of a TA in classrooms allowed for quicker responses to students' questions without the reported feelings of being intimidated or afraid to ask questions when compared to asking their instructor questions (Crowe et al., 2014).

\section{Faculty Satisfaction}

Faculty satisfaction has been shown to be positively influenced by the inclusion of TAs in courses. Lowenthal et al. (2019) found faculty identified interaction, grading, and lack of time as the leading challenges with highenrollment online courses. TAs provide faculty with added support to assist students on a regular basis. This extra resource allows faculty to concentrate on teaching and revising the content of course materials. Therefore, the TA gives greater reinforcement of content and insight to amplify student interest, interaction, and satisfaction of both students and faculty (Abbot et al., 2018). 
Not only do TAs assist with students, but they can also provide faculty with commentary on course material, allowing for improved teaching and future selection of content (Ritchey \& Smith, 2019). A study conducted by Gatlin and Alexander (2010) looked at both faculty and student satisfaction with having a TA in the course. Ninety-three percent of faculty surveyed reported having a TA in their course increased student satisfaction and facilitated assignment completion for greater feedback. The result was increased faculty satisfaction, which leads to the continued quality of instruction.

\section{Student Satisfaction}

It is widely known that the level of student engagement, instructor feedback, and instructor/student interaction, in not only brick-and-mortar universities but also online universities, is critical in determining student satisfaction. Talbot et al. (2015) found the majority of students agreed that having TAs in the classroom helped them learn, increased their satisfaction with the course, and enhanced their satisfaction with the teaching of the course.

In reviewing online programs with strong retention rates (80\% or above), Hart (2012) identified two recurring themes. First, the initial courses of a program are significant in terms of students deciding to either remain or drop out. Second, students demonstrate persistence when they have higher levels of interaction with peers and instructors. The lack of social interaction between students and then between the teacher and students represents a major factor in the decision to withdraw from an online program. This finding shows how important it is for students to feel engaged, valued, and immediately satisfied in their online learning experience.

\section{Materials and Methods}

The development of a TA program served as an opportunity for one fully online university to improve learning effectiveness, access to faculty and resources, faculty satisfaction, and student satisfaction, as well as retention and overall scale (cost-effectiveness) through stronger interaction methods in all first-year courses and several upper-level courses identified as high-risk courses. High-risk courses were identified as having high failure or non-completion rates.

This study evaluated a 3-year TA program based on the following research questions:

1. Did the inclusion of TAs in online undergraduate courses have an impact on learning effectiveness?

2. Did the inclusion of TAs in online undergraduate courses have an impact on scale (cost-effectiveness and commitment)?

3. Did the inclusion of TAs in online undergraduate courses have an impact on access?

4. Did the inclusion of TAs in online undergraduate courses have an impact on faculty satisfaction?

5. Did the inclusion of TAs in online undergraduate courses have an impact on student satisfaction?

\section{The Context of the Study}

The study university is accredited by the Higher Learning Commission and began serving working adults seeking to earn a doctoral degree in 1970 . Today the university has over 55,000 students from across 50 states and in more than 165 countries. It is ranked number one among 370 accredited United States institutions for awarding doctorate degrees to African Americans (National Science Foundation, 2019). With over 144,000 alumni spanning the globe, it continues to live its mission of effecting positive social change. 
The specific school has programs at all degree levels: undergraduate, master's, and doctoral. Students in the undergraduate programs are diverse and mature. The current undergraduate population includes $39.5 \%$ White, 29.9\% African American, and 7.6\% Asian. The majority of undergraduate students are over the age of 24 (77.7\%), which would be considered non-traditional college age, and, in fact, $59.9 \%$ are age 30 or older. In addition to their academic responsibilities, they are employed, with many in the health field. Most of the undergraduate students are active parents to children under the age of 18 , and the university is seeing an increase in grandparents as students. Students' motivation to succeed and to make a better life for their family is very strong; however, their preparation to perform well in college is often not of equal measure. Thus, some of the study university's undergraduate students need significant support from the university, including an understanding of the most basic elements of online education and foundational undergraduate skills, such as academic writing and basic mathematics. Many students are also first-generation college students and are not surrounded by strong cultures of education.

All faculty in the school have terminal degrees. The undergraduate courses average enrollment of 24 students. Undergraduate first-year courses and high-risk courses (those with high attrition and/or fail rates) were earmarked as opportunities for TAs to provide student and faculty support while gaining teaching experience as they complete their degrees.

The TA job description was sent out via several student communications to all doctoral students in the school. Each TA went through the standard hiring process of resume submission, panel interviews, and background checks. The criteria to serve as a TA was that they remained enrolled as a graduate student during the time commitment. The payment was a $\$ 500$ monthly stipend. Once a student graduated, serving as a TA was no longer an option.

Once hired, the TAs went through 2 weeks of training. Their onboarding included 13 self-paced modules previously developed for faculty at the university. All training modules were located in a private course shell in Blackboard LMS. The required training modules included the following topics: FERPA, academic integrity, university policies, working with adult learners, engaging diverse learners, facilitating online discussions, building community, providing feedback and grading, and disability services. Certificates of completion were uploaded into the grade book and reviewed by the program director. In addition to the training modules, TAs were required to attend a group orientation meeting with the director and, subsequently, individual meetings with their mentoring faculty member. The program director was responsible for TA course and faculty assignments, as well as outlining the division of responsibilities between faculty and TA within each course.

The 15 TAs included three males and 12 females. Five were African American, 10 were White, and one was an international student, while the rest $(n=14)$ lived inside the U.S. The TA minimum expectations included introducing themselves to students in the class café; logging into the classroom a minimum of four days per week; posting within the discussion area a minimum of 4 days per week; responding to student email inquiries within 24 hours; offering live office hours each week (either via Skype or IM); providing additional resources for students in the doc sharing area of the course, and completing the end-of-course survey as directed. Above all, the TAs' main role was to provide much-needed support to the students new to online education and/or lacking basic academic skills. TAs' responsibilities included consistent outreach to students who went missing or were struggling, connecting them to university support services, navigating the learning management system, acclimating students to the online academic environment, and reinforcing writing requirements. TAs were also responsible for grading certain assignments, as outlined by the program director in collaboration with the faculty member, as shown in Figure 1. 
Figure 1: Faculty and Teaching Assistant Grading Responsibilities

\begin{tabular}{|c|c|c|}
\hline Assignment & Faculty Member & TA \\
\hline $\begin{array}{l}\text { 1. Week 2-Article Review of } \\
\text { Social Determinants }\end{array}$ & $\begin{array}{l}\text { 1. Grade all assignments } \\
\text { 2. Review TA grading }\end{array}$ & $\begin{array}{l}\text { 1. Review faculty member's grading } \\
\text { 2. Grade all Week } 4 \text { assignments }\end{array}$ \\
\hline $\begin{array}{l}\text { 2. Week 4-Evaluating Online } \\
\text { Health Information }\end{array}$ & 3. Grade all assignments & 3. Review faculty member's grading \\
\hline $\begin{array}{l}\text { 3. Week } 5 \text {-Health Organization } \\
\text { and Non-Profit Agencies }\end{array}$ & & \\
\hline Weekly Discussions (Weeks 1-6) & $\begin{array}{ll}\text { - } & \text { Respond to } 2 / 3 \text { of } \\
\text { students }\end{array}$ & $\begin{array}{l}\text { - } \begin{array}{l}\text { Respond to a minimum of } 10 \\
\text { students }\end{array} \\
\text { - } \quad \text { Review faculty member's grading } \\
\text { and feedback }\end{array}$ \\
\hline My Health Journal (Weeks 1-6) & & - Grade all \\
\hline
\end{tabular}

\section{Data Collection}

To analyze the TA program outcomes at the study university, we employed a mixed-methods approach with a variety of assessments and data collection methods. The OLC's five pillars, in alignment with the research questions, were used to guide the data collection and analysis. Indirect assessments included the annual satisfaction survey administered to all students by the Office of Assessment, which was used to analyze faculty satisfaction, student satisfaction, and scale.

Direct assessments consisted of next-term retention and final grades in courses with TAs (2016-2017) compared to courses without TAs (2015-2016). These data points were used to measure learning effectiveness. The Office of Assessment's annual learning outcome reviews were also used to directly assess the impact of TAs in specific courses. The learning outcome reviews analyze detailed course assignments aligned to the program learning outcomes, identifying where students were doing well, where they struggled, and where the program could make curriculum improvements to enhance student learning and increase student success. Data gathered from the annual surveys and assessments was used to analyze learning effectiveness, scale (cost-effectiveness), access to resources, faculty satisfaction, and student satisfaction. Data from these reviews was not only used to evaluate the TA program but was also used before the implementation of the TA project. It displayed the courses where students were struggling and, therefore, where TAs would be placed.

An end-of-course evaluation developed by the researchers, based on the university's standard end-of-course evaluation and the five pillars, was administered in order to measure learning effectiveness, access to resources, student satisfaction, and faculty satisfaction. The surveys were created and distributed via a link from SurveyMonkey. At the end of every term, each of the three groups: (a) the test group (undergraduate students in courses with TAs), (b) the TAs, (c) and the faculty mentors received and responded to their respective survey.

The main program improvement made during the 3 years (2016-2017, 2017-2018, and 2018-2019) was the implementation of the TA program. Over this same period, 768 students in the test group provided quantitative feedback, with 269 providing qualitative feedback. For the TA group, 129 provided quantitative feedback, with 107 providing qualitative feedback. And, for the faculty mentor group, 138 provided quantitative feedback and 86 provided qualitative feedback. 
Figure 2: Alignment of Research Questions to Data Collection/Analysis

\begin{tabular}{ll}
\hline Research Question & Data Collection/Analysis \\
\hline Did the inclusion of TAs in online undergraduate & Retention rates \\
courses have an impact on learning effectiveness? & Final grades \\
& $\begin{array}{l}\text { End-of-term survey } \\
\text { Learning outcomes assessment }\end{array}$ \\
& Instructional delivery costs \\
$\begin{array}{l}\text { Did the inclusion of TAs in online undergraduate } \\
\text { courses have an impact on scale (cost-effectiveness } \\
\text { and commitment)? }\end{array}$ & Student satisfaction survey \\
$\begin{array}{l}\text { Did the inclusion of TAs in online undergraduate } \\
\text { courses have an impact on access? }\end{array}$ & Learning outcomes assessment \\
& End-of-term survey \\
$\begin{array}{l}\text { Did the inclusion of TAs in online undergraduate } \\
\text { courses have an impact on faculty satisfaction? }\end{array}$ & Student and faculty satisfaction surveys \\
$\begin{array}{l}\text { Did the inclusion of TAs in online undergraduate } \\
\text { courses have an impact on student satisfaction? }\end{array}$ & End-of-term survey \\
\hline
\end{tabular}

\section{Data Analysis}

The student satisfaction survey, faculty satisfaction survey, and learning outcome assessment are distributed and analyzed annually by the Office of Assessment. The learning outcome assessments were used to analyze learning effectiveness and access to resources. The student satisfaction and faculty satisfaction surveys were used to analyze student satisfaction, faculty satisfaction, and access to university resources. The four pillars were also analyzed through administration of the end-of-term course evaluations administered by the researchers to all TAs, faculty mentors (those with TAs in their courses), and all students in courses with TAs. Learning effectiveness was also analyzed through data gathered on retention and final grades. The additional research question that addressed scale (cost-effectiveness) was analyzed via operations data.

Certain parameters were applied to the analysis. For example, if a student failed HLTH 1005 as part of the control group, they were excluded from the analysis upon re-enrolling in HLTH 1005 with a TA (the test group). If a student took HLTH 1000 in Spring Quarter 2016 (control), and HLTH 1005 in Fall Quarter 2016 (either control or test), they were included only in the retention analysis for the control group due to Fall Quarter 2016 as the next consecutive course in the term after Spring Quarter 2016. If a student took HLTH 1000 in Winter Quarter 2015 (control) and a course in the "other" category in Spring Quarter 2017 (test), they were included in both the control and test retention analysis as it was a course-based analysis.

\section{Results}

\section{Learning Effectiveness}

\section{Retention}

For this study, next-term retention was analyzed with comparisons between the control group (2016 courses without a TA) and the test group (2017 courses with a TA), as shown in Table 1. 
Table 1: Next-Term Retention Comparison Analysis

\begin{tabular}{lcccccccc}
\hline Course N & \multicolumn{3}{c}{ Control Group (Courses with no TA) } & \multicolumn{3}{c}{ Test Group (Courses with TA) } \\
\cline { 2 - 8 } Sizes & 201610 & 201630 & 201650 & 201670 & 201710 & 201730 & 201750 & 201770 \\
HLTH 1000 & 47 & 43 & 66 & 63 & 54 & 75 & 77 & 76 \\
HLTH 1005 & 42 & 70 & 54 & 68 & 38 & 76 & 68 & 68 \\
PUBH 100O & 10 & 29 & 13 & 0 & 16 & 20 & 8 & 0 \\
Other & 0 & 0 & 68 & 178 & 0 & 0 & 65 & 160 \\
\hline
\end{tabular}

A chi-square test of independence was calculated comparing the control group to the test group. No statistically significant relationship was found $\left(\chi^{2}(1)=.042, p>.05\right)$. The findings show that enrolling in the next term appeared to be independent of whether the student had a TA in the previous course. The results are listed in Table 2.

Table 2: Next-Term Retention Results

\begin{tabular}{lcc}
\hline Course & $\begin{array}{c}\text { Test Group } \\
\text { (2017 Courses with TA) }\end{array}$ & $\begin{array}{c}\text { Control Group } \\
\text { (2016 Courses with no TA) }\end{array}$ \\
\hline HLTH 1000 $(n=501)$ & $75 \%$ & $72 \%$ \\
HLTH 1005 $(n=484)$ & $81 \%$ & $78 \%$ \\
PUBH 1000 $(n=96)$ & $86 \%$ & $75 \%$ \\
OTHER $(n=471)$ & $83 \%$ & $88 \%$ \\
\hline
\end{tabular}

Of interest, the second-year retention showed improvement over 3 years from January 2016 (66.7\%) to January 2019 (78.1\%). Further, overall retention improved 4\% since the implementation of the TA program in 2016.

\section{Final Grades}

A chi-square test of independence was calculated comparing the final grades of students in the control group to the test group (see Table 3$)$. No statistically significant relationship was found $\left(\chi^{2}(5)=9.174, p>.05\right)$. The findings display having a TA in the course appeared to be independent of the final grade students earned. An ANOVA was calculated to further display a statistically nonsignificant difference between the mean grade of courses with a TA versus courses without a TA ( $p$ >.05).

Table 3: Final Grades

\begin{tabular}{lcccccc}
\hline Final Student Grades & W & F & D & C & B & A \\
\hline $\begin{array}{l}\text { Control Group } \\
(2016 \text { Courses with no TAs) }\end{array}$ & $1 \%$ & $13 \%$ & $4 \%$ & $12 \%$ & $22 \%$ & $48 \%$ \\
$\begin{array}{l}\text { Test Group } \\
(2017 \text { Courses with TAs) }\end{array}$ & $1 \%$ & $14 \%$ & $5 \%$ & $12 \%$ & $27 \%$ & $42 \%$ \\
\hline
\end{tabular}

\section{Learning Outcomes}

Learning outcomes measuring effectiveness are analyzed annually by the university's Office of Assessment. The assessment analyzes specific course assignments aligned to the program learning outcomes. The grade 
columns for 2016 and 2018 for each control and test group indicate the percentage of students meeting the university's standard, set at or above $80 \%$ on a selected assignment. The failure columns for each of the respective groupings indicate the percentage of students failing the selected assignment. In total, 16 out of the 26 assignments (61.5\%) analyzed from 2016 to 2019 indicated an improvement in learning outcomes as demonstrated by resulting grades and measured learning effectiveness since the implementation of TAs to the aligned courses. The results indicate an overall increase in grades and a decrease in failure rates in the test group compared to the control group on the analyzed assignments in four out of the five course assignments. The results are listed in Table 4.

Table 4: Learning Outcomes

\begin{tabular}{lcccc}
\hline Assignment & $\begin{array}{c}\text { Control Group } \\
\text { Grades } \\
\mathbf{( 2 0 1 6 )}\end{array}$ & $\begin{array}{c}\text { Test Group } \\
\text { Grades } \\
\mathbf{( 2 0 1 8 )}\end{array}$ & $\begin{array}{c}\text { Control Group } \\
\text { Failures } \\
\mathbf{( 2 0 1 6 )}\end{array}$ & $\begin{array}{c}\text { Test Group } \\
\text { Failures } \\
\text { (2018) }\end{array}$ \\
\hline $\begin{array}{l}\text { HLTH 1000 } \\
\text { Discussion Week 5 }\end{array}$ & $79.3 \%$ & $86.3 \%$ & $9.6 \%$ & $8.3 \%$ \\
HLTH 1000 & $76.7 \%$ & $82.2 \%$ & $12.4 \%$ & $8.5 \%$ \\
Discussion Week 6 & $93.3 \%$ & $92.0 \%$ & $3.3 \%$ & $4.5 \%$ \\
HLTH 1005 & & & & \\
Discussion Week 2 & $82.4 \% \%$ & $91.3 \%$ & $6.6 \%$ & $4.3 \%$ \\
HLTH 2110 & & & & \\
Discussion Week 6 & $81 \%$ & $94 \%$ & $10.6 \%$ & $6.0 \%$ \\
HLTH 3110 & & & & \\
Assignment Week 3 & & & &
\end{tabular}

\section{Scale: Cost-Effectiveness and Commitment}

Before implementation of the TA program, program courses were maxed out at 24 students before another section was opened. After implementation, first-term courses were maxed out at 30 students, reducing the need for opening additional sections. Compared to the other nine programs in the school, this program, with the addition of the TAs, continues to have the lowest instructional delivery (ID) costs and increasing program revenue, according to the operations team. The lower ID costs resulted in a sustained institutional commitment from higher leadership (e.g., deans and vice provosts), with the TA program being continued (4 years now) and implemented in other schools across the university.

The higher enrollment in courses does not appear to impact students negatively. According to the 2018 student satisfaction survey, in the 2017 academic year, $96 \%$ of the students $(n=111)$ reported "yes" to the question, "do/did you find the typical size of your classes are/were conducive to your learning?" This was an increase from the 2016 academic year in which $93.5 \%$ of the students $(n=87)$ replied yes to the same question.

\section{Access}

Access includes three areas of support which are (a) academic (e.g., tutoring, advising, and library), (b) administrative (e.g., financial aid and disability services), and (c) technical (e.g., hardware reliability and uptime, and help desk) (OLC, 2020). The TAs in the program was responsible for helping undergraduate 
students connect to all university support services noted above and served as tutors. Undergraduate students left the following feedback in end-of-course evaluations regarding TAs' academic support and impact on access:

- My TA went extra miles in helping me achieve my goal, especially in quick response to figure out how to solve my problem, I really appreciate having her.

- I enjoyed having more than one person to use as a reference.

- TA X was awesome! She answered every question very quickly, even by text outside of her office hours, and did everything she possibly could to help, even with technical difficulties. She was easy to talk to, helpful, and gave good feedback in a constructive way.

- I highly appreciated the APA tips the TA provided.

- The TA in my class was instrumental in helping me develop my problem statement and research design.

- Our TA assisted me by offering guidance and examples of how to improve my writing and encouraged me to utilize the writing center to improve my writing.

- Having a TA in the classroom gives students the freedom to ask questions they may not feel comfortable asking the professor.

- The assignments were graded much quicker thanks to the multiple offers of assistance.

- $\quad$ TA X was wonderful! When I got discouraged, she found a way to make me feel better and she always knew just the right things to say to help encourage me. She offered so much help and truly went the extra mile to make sure I was going to be successful! She is a true gem!!

- The TA program is a valuable asset to the instructors and helps us with students who are having difficulty and adds another level of expertise for the students to access. I appreciate having a TA in my class.

One faculty member commented, "The TA was so accessible, it made me [the faculty member] feel like a slacker; I had to up my game.” Therefore, more faculty access was provided to students.

\section{Faculty Satisfaction}

Faculty satisfaction surveys are distributed annually through the Office of Assessment and are rated on a scale of very dissatisfied to very satisfied. According to the 2015 faculty satisfaction survey, completed prior to the TA program, $100 \%$ of the program's faculty $(n=24)$ were satisfied to very satisfied being a faculty member at the study university, compared to $70 \%$ of faculty $(n=10)$ in 2018 . And, almost all faculty $(97 \%, \mathrm{~N}=23)$ in 2015 reported the likelihood they would still be a part of the university 5 years later, compared to $80 \%$ in 2018. Although positive trends were not evident according to the faculty satisfaction data, the results should be interpreted with caution. First, the faculty response rate in 2018 was substantially lower compared to 2015, so this should be considered. Second, faculty satisfaction surveys do not report the faculty respondents with and without TAs, which could influence faculty satisfaction. Finally, although no major changes were made to the course content over the 3-year evaluation period, there was a change in program leadership in 2016, which could have influenced response rates, impacted satisfaction, and reported results.

On the other hand, direct assessment results, those given only to faculty who work directly with the TAs, from the faculty end-of-course evaluations indicated high satisfaction levels with the TA program. When asked if they believed the TAs displayed content knowledge in the classroom, faculty reported a $97.8 \%$ rating of "always" $(n=137)$. As shown in Table 5 , the majority of the faculty, at $86.9 \%(n=137)$, also agreed the 
presence of TAs better supported the students. Additionally, 90.5\% $(n=137)$ stated the faculty felt better supported with TAs.

Table 5: Faculty Satisfaction of Teaching Assistant Program

\begin{tabular}{lc}
\hline Artifact & $\begin{array}{c}\text { Yes } \\
(N=137)\end{array}$ \\
\hline The TA respected (e.g., did not overstep) your role as the faculty member. & $99.3 \%$ \\
The TA's presence in the classroom appears to have better supported the students. & $86.9 \%$ \\
The TA's presence in the classroom better supported you. & $90.5 \%$ \\
$\begin{array}{l}\text { Do you perceive the TA's presence and assistance in the course to have positively } \\
\text { impacted student progress and retention? }\end{array}$ & $81.9 \%$ \\
\hline
\end{tabular}

Furthermore, before the implementation of the TA program, faculty frequently reached a level of burnout when teaching the first-term courses. When compared to higher-level courses, surveyed faculty reported spending 30\% more time on support-related activities. This included student outreach, connecting students to university services, navigating the learning environment, and reinforcing basic writing skills. With the TAs, faculty commitment to teaching first-term courses has significantly improved as the TAs are responsible for supporting many of the first-term students' supplemental needs, facilitating confidence in their online learning abilities.

Faculty were also asked to share open-ended feedback about the TA program. Faculty qualitative comments included:

- TA X did a wonderful job supplementing my work. She was energetic, interesting, and extremely interactive with the students. She has expressed an interest in online teaching when she finally earns her degree. I would absolutely recommend her for a job if I were asked to be a resource. She is knowledgeable and ready to do good work and takes the wheel when she is at the helm. She was able to put out fires effectively and was a real asset to me.

- TA X did a fantastic job of engaging with students. Her feedback was detailed and constructive. She took initiative and was very responsive to my inquiries as well as questions from students.

- TA X and I have been testing strategies together to increase student retention over the last three terms. We can see the additional outreach pay off. I cannot imagine teaching an introductory class without a TA now. They add a level of assistance that is so helpful in this type of course.

- The TA project is a valuable asset to the instructors and helps us with students who are having difficulty and adds another level of expertise for the students to access. I appreciate having a TA in my class.

- TA X was such an asset to our HLTH 1000 course. She provided additional support to many students who needed it. Thank you for continuing with this project!

- Such a great project! The students benefit from the additional attention and it is great for the faculty to mentor a doctoral student.

- Having a TA in HLTH 1000 was a game-changer. I will continue to teach it as long as I have a TA in there with me. Otherwise, I prefer to teach a higher-level course. 


\section{Student Satisfaction}

Student satisfaction surveys are distributed annually through the Office of Assessment and are rated on a scale of $\mathrm{o}$ to 10, with $\mathrm{o}$ being very dissatisfied and 10 being very satisfied. The university considers scores of 8 to 10 acceptable; therefore, it is the standard for what was considered in this study. According to the 2015 student satisfaction survey, before the implementation of the TA program, $72 \%$ of the program's students $(n=$ 275) were satisfied to very satisfied (8-10 rating) with the university. In 2018, post-TA-program implementation, $78 \%(n=137)$ reported being satisfied to very satisfied. In $2015,74 \%$ of the students $(n=$ 274) were likely to very likely (8-10 rating) to recommend the university to others. When compared to 2018 and the addition of TAs, $77 \%(n=138)$ were likely to very likely to recommend the university to others. Further, in 2015, 86\% of the students $(n=267)$ reported being satisfied with "most" or "all" of their professors, compared to $87 \%$ of the students $(n=133)$ in 2018.

Consequently, student perceptions of faculty caring about their success did not change over the 3-year period, maintaining an 80\% reported "agree to strongly disagree" in $2015(n=265)$ and $2018(n=134)$. Though small, results are more favorable toward student satisfaction of the TA program, although the same limitations as noted above (lower response rate in 2018 and student satisfaction surveys not reporting the student respondents with and without TAs) should also be considered.

Additionally, according to the end-of-term surveys (see Table 6), approximately $64.3 \%(n=768$ ) of students enrolled in courses with TAs stated the TA played a role in their academic success during the course. Students who took a course with a TA reported the TA's presence in the classroom better supported them $(65.1 \% ; n=$ $756)$ and $73.2 \%(n=762)$ noted that having a TA in a future course would be helpful. When students were asked about the TA's contribution to the discussion board as being individualized, probing, and educational, $76.5 \%$ reported "always" ( $n=761$ ). One student commented, "What I got out of the TA's presence more than anything was from his responses to our discussion boards. I was able to learn from his replies/questions as well as how he formatted his writing."

Table 6: Undergraduate Student Satisfaction of Teaching Assistant Program

\begin{tabular}{lc}
\hline Artifact & $\begin{array}{c}\text { Yes } \\
(\mathbf{N}=\mathbf{7 6 8})\end{array}$ \\
\hline Do you think having a TA in future courses would be helpful? & $73.2 \%$ \\
Did the TA play a role in your success? & $64.3 \%$ \\
The TA's graded feedback was individualized, substantive, and highlighted areas of & $75.9 \%$ \\
strength and areas needing improvement. & $26.6 \%$ \\
I contacted the TA outside of the classroom. & \\
\hline
\end{tabular}

Negative qualitative comments left by students on the end-of-course evaluations were limited and centered on TAs taking away from the interaction with faculty, but are shared here:

- The TA's presence was a distraction from the professor, and I didn't find it helpful.

- While TAs are good to have, they are surely not a replacement for the direct involvement of the experienced teaching faculty, especially when their years of experience, sharing insights to the students, are necessary for the overall success of the student. 
- Useless and nothing but repeating the professor's response. Waste of student's tuition and fee for having TA.

- I really do not like the idea of having a TA in my classroom because it takes away from students interacting with the teacher as a whole.

Finally, although there was not student satisfaction comparison data available for the graduate students serving as TAs to those who did not participate in the program, it is important to include their perspectives of the program. TAs were surveyed by the end-of-term survey with qualitative and quantitative questions. The majority ( $85.8 \% ; n=143$ ) of TAs reported "always" feeling achievement helping students learn. TAs reported that about half (49.3\%) of students used their live office hours. The end-of-course qualitative feedback included:

- The highlight of being a TA was the students reaching out for assistance and giving feedback that they appreciated the help.

- As the TA is a student, we share the same perspective in the desire to show competence in coursework. I feel this offers less judgment and a greater level of comfort asking for clarity with assignment instructions.

- Being a TA has made me more than an agent of social change, it has made me an ambassador for social change by allowing me to contribute to real change by having an impact on undergraduate students' success.

- I believe I have become a better Ph.D. student with eyes that can see what other professors are looking for. I have a great respect and time tolerance awaiting papers and chapters to be graded. This really can be time-consuming, and each professor wants the best for each one of us.

- The first thing I like to do as a TA is to show students how to improve their grades by making it simpler for the professor to identify if the discussion questions were answered by including them in the discussion post. See the questions, read the answers, award credit.

The feedback received from the TAs in the program was overwhelmingly positive and supportive of student's comments and perceptions. However, a few TAs expressed ways to improve the program:

- I would want more encouragement from the faculty for students to respond to the TA.

- I would love to have meetings with the other TAs.

- I'd like to be able to rotate courses each term.

Many of these comments were addressed and the program was revised based on TA feedback. For instance, TAs are assigned different courses and mentoring faculty are rotated and a few TA meetings were organized to share best practices.

\section{Discussion}

This study evaluated a TA program at one fully online university. In a review of the findings, several positive indicators show that the implementation of a TA program is a useful strategy to enhance the quality of an online program. 


\section{Learning Effectiveness}

The results indicated the implementation of TAs in high-risk undergraduate courses did have a positive impact on learning effectiveness. More than half (61.5\%) of the assignments analyzed during the learning outcome review process from 2016 to 2019 indicated an improvement in student performance. Improvements in second-year (by 11.4\%) and overall retention (by 4\%) were observed during this timeframe. These findings are consistent with the literature noting the inclusion of TAs in courses leads to enhanced course learning outcomes and higher retention rates (Crowe et al., 2014; Huffmyer \& Lemus, 2019).

While no statistically significant relationships were identified when comparing the control group (2016 course without TAs) to the test group (2017 courses with TAs) in the outcome on next-term retention and student final grades, limitations affecting both quantitative responses and available faculty deserve merit. The responses of student surveys in a predetermined organized response system may display a bias among other considerations to continuing their education. For example, it is difficult to determine if TAs were the single variable leading to improvement of learning effectiveness as the changes could have been influenced by other factors external to the program, such as enrollment of stronger students. Further, comparisons were not exact as different faculty were included within the analysis among the comparable courses, which could have an impact on outcomes.

\section{Scale: Cost-Effectiveness and Commitment}

TAs provided added resources and student support for larger class sizes to exist, upwards of six students per section as noted in this study, and for a fraction of the pay as professors, approximately $25 \%$. TAs were a crucial variable in lowering this program's instructional delivery costs, ultimately leading to increased university revenue. The results from this study are consistent with the literature demonstrating that the inclusion of TAs in the online classroom is a method potentially enhancing cost-effectiveness while allowing universities to increase course enrollment and offerings without compromising a student's learning experience and satisfaction (Herrman \& Waterhouse, 2010).

Almost all students in this study (96\%) responded positively to the statement, "the class size was conducive to learning." As such, having TAs in the program allowed leadership at this university to align with the OLC mission to offer "the best educational value to learners and to achieve capacity enrollment" (OLC, 2020, para. 3).

\section{Access}

TAs in this study were responsible for assisting undergraduate students in navigating the online learning management system, connecting to university services, and acting as an academic support agent. Qualitative feedback provided by students in this study noted "quick responses," "more than one person to assist," "texted solutions outside of office hours," and "assisted with technical difficulties," aligning with the literature noting the presence of a TA in classrooms allowed for quicker responses to students' questions, individualized feedback, and a reduction in the feelings of being intimidated or afraid to ask TAs questions compared to their instructor (Conner \& Rubenstein, 2014; Crowe et al., 2014; Gatlin \& Alexander, 2010).

\section{Faculty Satisfaction}

Although faculty satisfaction, in general, appeared to have declined over the period studied, faculty directly involved in the TA program showed high satisfaction rates with the TA program. Most faculty, 86.9\%, agreed the presence of TAs better supported the students, and 90.5\% felt better supported with TAs. Faculty commented that TAs "were a real asset," "extremely engaged and responsive to students," "provided detailed and constructive feedback," "collaborated on retention strategies and outreach efforts," and "added helpful 
assistance." Faculty in this study noted their enhanced ability to concentrate on teaching and the course material. This conclusion is consistent with previous findings of having a TA in a course (Abbot et al., 2018; Gatlin \& Alexander, 2010).

Faculty also reported less burnout and higher levels of commitment to teaching first-year courses, thanks to the TAs support of student supplemental needs. One faculty commented, "I will continue to teach HLTH 1000 as long as I have a TA, otherwise, I prefer a higher-level course".

Finally, faculty expressed a desire to "step up their game," leading to an improvement in their teaching, as a result of the addition of a TA, which is also consistent with the literature (Ritchey \& Smith, 2019). Begley et al. (2019) reported faculty participants appreciating both the classroom logistical support provided by the TA along with the collegial partnership.

\section{Student Satisfaction}

The results of this study revealed TAs in online courses had a positive impact on student satisfaction with the university ( $72 \%$ in 2015 to $78 \%$ in 2018 ), likelihood to recommend the university to others ( $74 \%$ in 2015 to $77 \%$ in 2018), and satisfaction with professors (86\% in 2015 to $87 \%$ in 2018). Furthermore, $62 \%$ of the students believed TAs played a role in their success, with $65 \%$ feeling better supported in their learning achievements and 73 noted that having a TA in a future course would be helpful. Again, these results are consistent with the literature stating the level of engagement, feedback, and instructor/student interaction is critical in determining student satisfaction, especially in the first few courses of a program (Abbot et al., 2018; Gatlin \& Alexander, 2010; Hart, 2012).

\section{Limitations and Future Research}

With these findings preliminary to a 3-year exploratory study to measure the integration of TAs in the online classroom, there are several limitations when generalizing the results to other academic programs. The scope of participation was limited to an undergraduate program within one school at a fully online university. Additionally, the participants were non-traditional students located in various geographical locations of the U.S. and abroad. According to Asare (2014), gender and ethnicity impact the classroom experience lending to differences in culture limiting social interactions. The proximity of students within a regional-based university may indicate greater communication toward student satisfaction rather than with the added resources of a TA.

As the university in this study is fully online, the faculty, as well as the TAs, were sufficiently prepared through several online methods of training and pedagogy. Equally important, the TAs had considerable familiarity and experience with the learning management system as they share the same student status within the school, although in a graduate-level program. In many institutions making the transition to online or hybrid classes, faculty report feeling challenged by the nature of online teaching and the adaptation of materials (GillettSwan, 2017). Further, faculty still prefer the face-to-face level of instruction due to the higher time commitment of online instruction (Bourelle et al., 2015). While the inclusion of a TA program offers a greater potential of faculty satisfaction, necessary access to technology and further faculty online orientation should not be overlooked by university support services.

Lastly, there are inherent issues of social desirability bias with self-reported, scaled-type responses in any study. The supportive role of the TA sustains student involvement through on-going communications resulting in extra attention toward students. These layers of interactions and exchanges maximize opportunities resulting in student achievement. However, if the student did not meet their own coursework expectations, their perception may not be positive. As determined by Tichavsky et al. (2015), there is no welldefined distinction to the role that instruction contributes to student perceptions, attitudes, and 
achievements. If possible, the inclusion of focus groups may offer insights not previously available to determine sufficient reasoning for integrating and maintaining a TA program.

\section{Conclusion}

Understanding the impact of TAs in the online classroom has surfaced as an elemental factor in delivering an engaging online classroom. Future research should continue to build on findings in this research study by assessing the effectiveness of a TA program and the impact on the Five Pillars of Quality Education over a longer instructional period (OLC, 2020). Continued efforts to review the optimal student-to-faculty-and-TA ratio for online classroom engagement should also be a focal point (Lowenthal et al., 2019). TA program impact for courses in additional academic disciplines, gender, age-range, ethnicity, residential location, and graduate-level online courses will support the understanding of student learning achievements across varied student demographics.

The formal instructional training TAs receive also needs to be evaluated. Online instructional training for discussion engagement, assignment feedback, instructional behavior, and application of learning style for the online classroom can impact the effectiveness of a TA's instructional aptitude (Huffmyer \& Lemus, 2019). Finally, determining variables influencing the students' experiences in an online course contributing to perceptions, attitudes, accessibility, TA effectiveness, and skill and conceptual learning gains can provide insights into the unanswered research gaps of developing and managing a TA program in a virtual world of online education (Huffmyer \& Lemus, 2019). 


\section{References}

Abbot, S., Graf, A. J., \& Chatfield, B. (2018). Listening to undergraduate peer tutors: Roles, relationships, and challenges. International Journal of Teaching and Learning in Higher Education, 30(2), 245-261. http://www.isetl.org/ijtlhe/pdf/IJTLHE3059.pdf

Asare, K. (2014). Looking beyond the residential education and distance education debate, what matters in education is.... Turkish Online Journal of Distance Education, 15(3), 143-154. https://doi.org/10.17718/tojde.34665

Beaver, W. (2017). The rise and fall of for-profit higher education. American Association of University Professors. https://www.aaup.org/article/rise-and-fall-profit-higher-education\#.XwgrlohKioo

Begley, G., Berkey, R., Roe, L., \& Schuldt, H. (2019). Becoming partners: Faculty come to appreciate undergraduates as teaching partners in a service-learning teaching assistant program. Internal Journal for Student as Partners, 3(1), 89-105. https://doi.org/10.15173/ijsap.v3i1.3669

Bourelle, T., Bourelle, A., \& Rankins-Robertson, S. (2015). Teaching with instructional assistants: Enhancing student learning in online classes. Computers \& Composition, 37, 90-103. https://doi.org/10.1016/j.compcom.2015.06.007

Carless, D., \& Boud, D. (2018). The development of student feedback literacy: Enabling uptake of feedback. Assessment \& Evaluation in Higher Education, 43(8), 1315-1325. https://doi.org/10.1080/02602938.2018.1463354

Conner, N. W., \& Rubenstein, E. D. (2014). The perceptions of the quality of education received by Ph.D. graduate teaching assistant instructors through the eyes of four agricultural education preservice teachers. North American College and Teachers of Agriculture, 58(1), 11-18. https://www.jstor.org/stable/nactajournal.58.1.11

Crowe, J., Ceresola, R., \& Silva, T. (2014). Enhancing student learning of research methods through the use of undergraduate teaching assistants. Assessment \& Evaluation in Higher Education, 39(6), 759-775. https://doi.org/10.1080/02602938.2013.871222

Gatlin, K., \& Alexander, P. (2010). Using clinical teaching assistants to foster student engagement in online courses. Journal of Instructional Pedagogies, 4, 1-14. https://www.aabri.com/manuscripts/10548.pdf

Gillett-Swan, J. (2017). The challenges of online learning: Supporting and engaging the isolated learner. Journal of Learning Design, 1O(1), 20-30. https://dx.doi.org/10.5204/jld.v9i3.293

Hart, C. (2012). Factors associated with student persistence in an online program of study: A review of the literature. Journal of Interactive Online Learning, 11(1), 19-42. https://www.ncolr.org/jiol/issues/pdf/11.1.2.pdf

Haynie, D. (2015, January 30). Experts debate graduation rates for online students. U.S. News \& World Report. https://www.usnews.com/education/online-education/articles/2015/01/30/experts-debategraduation-rates-for-online-students

Herrman, J., \& Waterhouse, J. (2010). Benefits of using undergraduate teaching assistants throughout a baccalaureate nursing curriculum. Journal of Nursing Education, 49(2), 72-77. http://dx.doi.org/10.3928/01484834-20090918-05

Hoessler, C., \& Stockley, D. (2016). How graduate students are supported in their teaching. Journal of Applied Research in Higher Education, 8(2), 146-158. https://doi.org/10.1108/JARHE-10-2014$\underline{0102}$ 
Huffmyer, A. S., \& Lemus, J. D. (2019). Graduate TA teaching behaviors impact student achievement in a research-based undergraduate science course. Journal of College Science Teaching, 48(3), 56-65. http://dx.doi.org/10.2505/4/jcst19 $048 \quad 03 \quad 56$

Lowenthal, P., Nyland, R., Jung, E., Dunlap, J., \& Kepka, J. (2019). Does class size matter? An exploration into faculty perceptions of teaching high-enrollment online courses. American Journal of Distance Education, 33(3), 152-168. https://doi.org/10.1080/08923647.2019.1610262

National Science Foundation. (2019). Survey of earned doctorates. https://www.nsf.gov/statistics/srvydoctorates/

Online Learning Consortium. (2020). Our quality framework. https://onlinelearningconsortium.org/about/quality-framework-five-pillars/

Ritchey, K. A., \& Smith, S. (2019). Developing a training course for undergraduate teaching assistants. College Teaching, 67(1), 50-57. https://doi.org/10.1080/87567555.2018.1518891

Supiano, B. (2017, November 15). Faculty members at one more university push back at online programs. The Chronicle of Higher Education. https://www.chronicle.com/article/Faculty-Members-at-OneMore $/ 241788$

Talbot, R., Hartley, L, Marzetta, K., \& Wee, B. (2015). Transforming undergraduate science education with learning assistants: Student satisfaction in large-enrollment courses. Journal of College Science Teaching, 44(5), 24-30. http://www.jstor.org/stable/43631844

Tichavsky, L. P., Hunt, A. N., Driscoll, A., \& Jicha, K. (2015). “It's just nice having a real teacher”: Student perceptions of online versus face-to-face instruction. International Journal for the Scholarship of Teaching and Learning, 9(2), n2. https://doi.org/10.20429/ijsotl.2015.090202

Weidert, J. M., Wendorf, A. R., Gurung, R. A., \& Filz, T. (2012). A survey of graduate and undergraduate teaching assistants. College Teaching, 6o(3), 95-103.

https://doi.org/10.1080/87567555.2011.637250

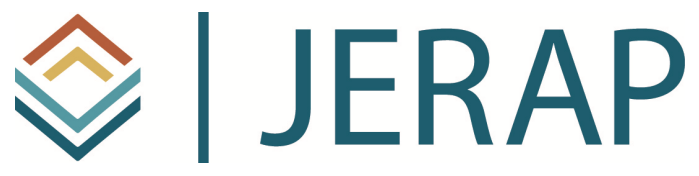

The Journal of Educational Research and Practice is a peerreviewed journal that provides a forum for studies and dialogue about developments and change in the field of education and learning. The journal includes research and related content that examine current relevant educational issues and processes. The aim is to provide readers with knowledge and with strategies to use that knowledge in educational or learning environments. JERAP focuses on education at all levels and in any setting, and includes peer-reviewed research reports, commentaries, book reviews, interviews of prominent individuals, and reports about educational practice. The journal is sponsored by The Richard W. Riley College of Education and Leadership at Walden University, and publication in JERAP is always free to authors and readers. 